Journal of Agricultural Sciences
(Tarim Bilimleri Dergisi)

\title{
Inbreeding in Holstein Friesian Cattle Population in Turkey
}

\author{
Ayşe Övgü ŞENa* ${ }^{*}$ D, Numan AKMAN ${ }^{\mathrm{B}}$

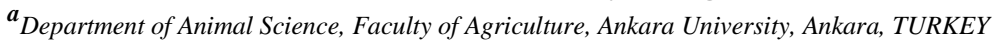 \\ ARTICLE INFO \\ Research Article \\ Corresponding Author: Ayşe Övgü ŞEN, E-mail: ayseovgusen@gmail.com \\ Received: 20 August 2020 / Revised: 01 April 2021 / Accepted: 14 April 2021 / Online: 25 March 2022
}

\section{ABSTRACT}

Inbreeding is generally associated with a reduction in production and profitability. Therefore, it is essential that it be monitored and kept under control. The purpose of this study was to calculate the inbreeding coefficient for Holstein Friesian cattle registered in the database of the Cattle Breeders' Associations of Turkey (CBAT). In this study, preherdbook and herdbook databases were combined. The database consisted of 6,935,005 individuals born between 1962 and 2012 Inbreeding coefficients were calculated using Wright's method, and ranging from zero to $43.75 \%$ with a mean of 0.0012 and standard deviation (SD) of 0.01273 for all animals, and considering the inbred animals, the mean inbreeding coefficient was 0.0106 and standard deviation was 0.03272 . The average inbreeding of all animals born in the population in 2012 was found to be 0.0022 . In the population, the proportion and the number of inbred individuals increased over the years, while the mean inbreeding coefficient decreased. This could be due to the fact that gene flow in the population from different countries was considerably high, and pedigree information was taken into account while importing sperm and live animals (both heifers and bulls)

Keywords: Relationship, Inbreeding, Holstein Friesian, Cattle

(C) Ankara University, Faculty of Agriculture

\section{Introduction}

Inbreeding is defined as the mating of individuals related to each other by ancestry (Falconer \& Mackay 1997), and is a growing concern in dairy cattle breeding (Weigel \& Lin 2002; Gullstrand 2015; Doekes et al. 2019). Especially the developments in the applications of artificial insemination (AI) during the past few decades have resulted in an increased use of few top sires all over the world, which has led to the spread of related offspring across different countries or even continents. For example, a few superior top Holstein bulls have sired about 250,000 milking daughters and 3,000 progeny-tested sons all over the world (Weigel 2001). In a study by Miglior (2000), it was found that the percentage of bulls born and sired by five bulls has increased from $25 \%$ to $47 \%, 61 \%$ and $55 \%$ in Europe, North America, and Oceania in 20 years, respectively.

Using relatively fewer bulls or increasing the number of progenies per bull in a selection program leads to an increase in genetic gain, but this may also decrease the genetic variance by inbreeding (Freyer et al. 2005; Gullstrand 2015). In other words, increased inbreeding decreases production traits (Thompson et al. 2000; Pryce et al. 2014), survivability (Sewalem et al. 2006), and reproductive performance (Adamec et al. 2006; Kaygısız \& Kösetürkmen 2007; Bayram et al. 2008; Hofmannova et al. 2019), which is known as inbreeding depression.

Controlling and monitoring of inbreeding levels are important in cattle populations to minimize the inbreeding depression (Wiggans \& VanRaden 1995; Weigel 2001; Freyer et al. 2005; Sorensen et al. 2005; Sewalem et al. 2006; Rokouei et al. 2010; Doekes et al. 2019). For example, the numbers of inbred cattle and their mean inbreeding coefficients are calculated every year for many breeds in the US, which are bred under the supervision of the United States Department of Agriculture (USDA), especially Holstein Friesian and Red Holstein breeds, and the results are posted on the website of the Council on Dairy Cattle Breeding (USCDCB 2021). Thus, the trend of the inbreeding coefficient of the Holstein Friesian population in the US can easily be followed.

Knowing the inbreeding coefficient is also significant for comparative studies of cattle populations from different countries. The objective of this study was to calculate the inbreeding coefficients of Holstein Friesian cattle registered by the Cattle Breeders' Associations of Turkey (CBAT). Although many studies investigated inbreeding levels of Holsteins as well as those of other breeds, no such comprehensive inbreeding analysis has been carried out in Turkey to date. 


\section{Material and Methods}

\subsection{Data}

This study used pedigree information regarding Holstein Friesian cattle breed in farms which are members of the Cattle Breeders' Associations of Turkey. The database of the study is comprised of two elements: (i) pre-herdbook and (ii) herdbook, including information about, for example, ownership, breeding and some production traits. In the pedigree, certain constrains were applied to improve the quality of the data. Therefore, some data from the file were not included in the analysis, and the applied constrains are summarized in Table 1.

Table 1- Reasons for excluding certain data in the analyses although they were included in the main pedigree file

\begin{tabular}{lr}
\hline Reason for exclusion from the dataset & Pedigree File \\
\hline Both parents were unknown & 1746241 \\
Dams were older than 13 years when the progeny was born & 18843 \\
The period between the birth of sire and their progeny was shorter than two years & 648 \\
Calving interval was shorter than 235 days & 1600 \\
Total & 1767332 \\
\hline
\end{tabular}

The records utilized in this study contained animal, sire and dam identification information, as well as sex, province and date of birth data. The inbreeding coefficients were calculated using pedigree records of Holsteins born between 1962 and 2012 , for $6,935,005$ individual animals, among which the longest ancestral path was 13 . There was recorded information for at least one parent for all of these individuals. $79.93 \%$ of the animals in the pedigree file consisted of individuals of which both parents were known.

\subsection{Analysis of data}

In this study, the coefficient of inbreeding for each animal was calculated using the MTDFNRM module of MTDFREML (Multiple Trait Derivative Free REstricted Maximum Likelihood (MTDFREML) software (Boldman et al., 1995). In the MTDFNRM module, inbreeding coefficient of individuals is calculated, as done in Wright's method, by halving the numerator relationships of each parent.

The inbreeding coefficient of animal $\mathrm{X}\left(F_{x}\right)$ is calculated as follows (Wright 1922):

$F_{x}=\sum_{C A=1}^{k}\left[\left(\frac{1}{2}\right)^{\left(n_{1}+n_{2}+1\right)}\left(1+F_{C A}\right)\right]$

Where; $\mathrm{CA}$ is a common ancestor of sire and dam of $\mathrm{X} ; \mathrm{k}$ is the number of common ancestors in the $\mathrm{X}$ 's, pedigree; $n_{1}$ is the number of generations separating the common ancestor from the sire of $\mathrm{X}, n_{2}$ is the number of generations separating the common ancestor from the dam of $\mathrm{X}$, and $F_{C A}$, is the inbreeding coefficient of the common ancestor.

The pedigree file was rearranged so that it meets the requirements of the MTDFNRM module. All records were sorted according their birth year and recorded appropriately. Then, all animals were sorted from the oldest the youngest. Some parents had no birth dates in the main file, so new birth dates were assigned by taking their oldest offspring into consideration. Mean inbreeding was calculated per year based on the birth year of the animals.

\section{Results and Discussion}

The number of animals included in the analyses was 6,935,005, whereas the number of animals born after 1990 was $6,931,329$. Of these, both parents were known for 5,543,259 individuals. In the pedigree, there were 278,907 full sib groups, and the average family size was 2.05 . The number of animals and their mean inbreeding coefficient with its standard deviation are presented in Table 2. The mean inbreeding coefficient and standard deviation were 0.0012 and 0.01273 , while, only with respect to the inbred animals, they were 0.0106 and 0.03272 , respectively. The highest inbreeding coefficient in this population was 0.4375 .

Table 2- Inbreeding coefficient of individuals in pedigree file

\begin{tabular}{llllll}
\hline Groups & $\boldsymbol{N}$ & Mean & Standard Deviation & Min & Max \\
\hline Whole population & 6935005 & 0.0012 & 0.01273 & 0 & 0.4375 \\
Inbred population & 962359 & 0.0106 & 0.03272 & 0.000015 & 0.4375 \\
\hline
\end{tabular}


In this study, inbreeding coefficients were calculated as lower than the ones included in the previous reports, in which the inbreeding coefficient was determined to be 0.026 for Holsteins born in 1990 by Wiggans \& VanRaden (1995), and the average inbreeding coefficient in elite Holstein cows and AI Holstein bulls was calculated as 0.042 and 0.044 , respectively, by Weigel and Lin (2002). The difference can be attributed to the fact that Turkey has been importing both semen and heifers continuously from other countries.

In Turkey, there are some studies that investigated the inbreeding level of Holsteins in the small-scaled herds, and their results are not similar to those found in the present study. Because their data were obtained from smaller and more closed populations compared to our population, which comprises a greater number of herds from all around the country. For example, some reports of the mean inbreeding coefficients were $1.35 \%$ in 439 animals (Bayram et al. 2008), 0.31\% in 293 animals (Okumuş et al. 2010), and $1.91 \%$ in 810 animals (Duru 2012).

Pedigree records used in this study started in 1962, but the records of only a small number of animals $(3,676)$ born before 1990 were available, and only five of these animals were inbred. Therefore, mean inbreeding coefficients were presented for the period between 1990 and 2012 (see Table 3 and Figure 1). The inbreeding rate was not stable over time and consisted of three periods in which inbreeding was changing at different rates. As seen in Table 3, between 1991 and 1996, inbreeding coefficient rose steadily from $5.85 \%$ to $7.68 \%$. However, after 1996 , it gradually decreased from $6.41 \%$ until it went down to $1.45 \%$ in 2005. From 2005 to 2012, the downward trend in inbreeding coefficient continued while fluctuating between $1.45 \%$ to $0.88 \%$ (see Table 3 and Figure 1). The annual rate of change in inbreeding between 1990 and 2012 was found as $-8.23 \%$.

Table 3- Annual mean inbreeding coefficients in inbred individuals between 1990 and 2012

\begin{tabular}{lccc}
\hline Birth Year & $\begin{array}{c}\text { Number of } \\
\text { Individuals }\end{array}$ & $\begin{array}{c}\text { Inbred Individuals, } \\
(\%)\end{array}$ & $\begin{array}{c}\text { Mean Inbreeding Coefficient, } \\
(\%)\end{array}$ \\
\hline 1990 & 2196 & 2.91 & 5.85 \\
1991 & 2744 & 3.53 & 5.35 \\
1992 & 4477 & 4.02 & 6.24 \\
1993 & 7484 & 2.78 & 6.75 \\
1994 & 9217 & 2.94 & 7.03 \\
1995 & 13461 & 2.38 & 7.61 \\
1996 & 19703 & 3.03 & 7.68 \\
1997 & 26143 & 2.76 & 6.41 \\
1998 & 37556 & 2.42 & 7.00 \\
1999 & 56940 & 2.38 & 5.58 \\
2000 & 80626 & 2.57 & 5.14 \\
2001 & 88874 & 4.05 & 4.65 \\
2002 & 112612 & 4.62 & 4.03 \\
2003 & 151632 & 4.37 & 3.45 \\
2004 & 225888 & 4.75 & 2.52 \\
2005 & 316635 & 5.48 & 1.45 \\
2006 & 540579 & 5.49 & 1.10 \\
2007 & 722436 & 6.52 & 0.97 \\
2008 & 744449 & 10.25 & 0.94 \\
2009 & 785488 & 14.58 & 1.00 \\
2010 & 889773 & 18.80 & 1.00 \\
2011 & 1136811 & 21.08 & 0.93 \\
2012 & 955605 & 24.86 & 0.88 \\
\hline
\end{tabular}

As seen in Table 3, mating of close relatives was avoided after 2003, while the number of distantly related animals with a common ancestor increased. In contrast to our findings, USCBDCB (2001) reported that the inbreeding coefficient for cows and bulls steadily increased after 1960, and the USCDCB 2021 Report showed that the inbreeding coefficient of cows for 2012 was $5.89 \%$, while it was $8.59 \%$ for 2020 . Moreover, Sorensen et al. (2005) reported the mean inbreeding coefficient for calves born in 2003 to be $3.9 \%$ in Danish Holsteins. In their study, the inbreeding trend was described as a smooth increase. Sewalem et al. (2006) reported the average levels of inbreeding for animals born in 2004, which was 3.20\% for Holsteins, 3.99\% for Ayrshires and $3.60 \%$ for Jerseys. In the same study, the magnitude of the inbreeding coefficient was observed to be increasing over time. In other words, inbreeding increased as pedigrees got deeper. However, in direct contrast to the studies cited above, in our study, inbreeding trends were observed to decline over time (see Figure 1). This result can be attributed to the fact that Turkey's Holstein population is not a closed one, that is, Turkey continued to import both semen and heifers every year from several other countries around the world (TUIK 2021). 


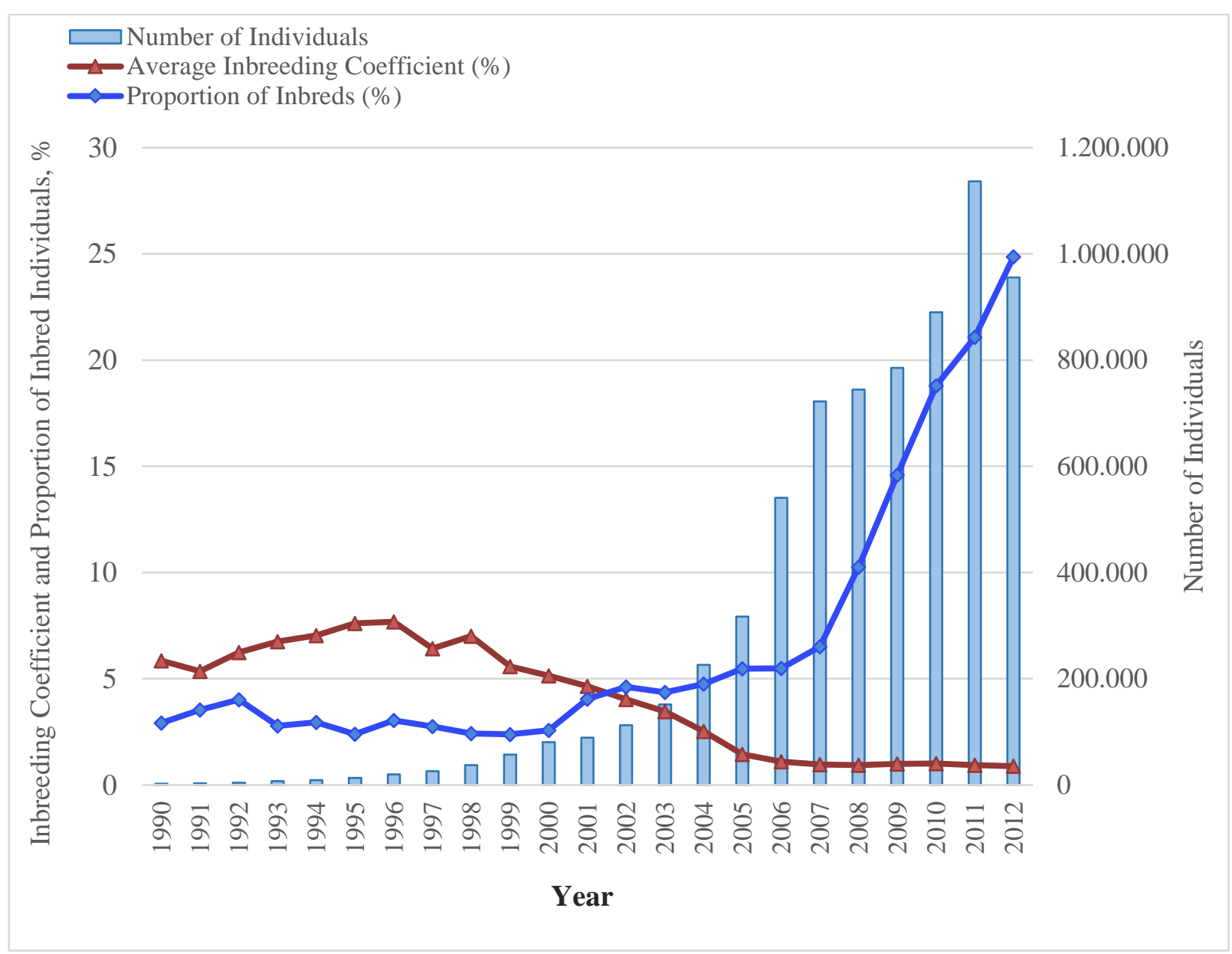

Figure 1- Number of individuals and the mean inbreeding coefficient from 1990 to 2012

The distribution of inbreeding coefficients is shown in Table 4. Most individuals $(92 \%)$ had an inbreeding coefficient less than or equal to $2.50 \%$. In this population, the inbreeding coefficient was greater than $12.50 \%$ only for $1.86 \%$ of inbred animals. In other words, an overwhelming majority of the inbred individuals had an inbreeding coefficient below $12.50 \%$. Usually, the mating of half-sibs would result in a $12.50 \%$ expected inbreeding coefficient, but the modern practice of using the sperm from the same sires over a period of many years leads to an increase in the number of inbred animals. This results in inbreeding coefficients greater than $12.50 \%$ in the population due to accumulated relationships among animals. Mc. Parland et al. (2007) reported that $0.80 \%$ of all Holstein-Friesian cross in the population had an inbreeding coefficient greater than $12.50 \%$. Hofmannova et al. (2019) reported that $0.39 \%$ of Czech Holsteins had an inbreeding coefficient over $10 \%$.

Table 4- Distribution of individuals based on different inbreeding levels and birth years

\begin{tabular}{|c|c|c|c|c|c|c|}
\hline \multirow{2}{*}{ Inbreeding Class ${ }^{1}$} & \multirow{2}{*}{$\begin{array}{r}\text { Born between } \\
1990 \text { and } 2012^{2}\end{array}$} & \multicolumn{5}{|c|}{ Birth Year } \\
\hline & & 2008 & 2009 & 2010 & 2011 & 2012 \\
\hline $\mathrm{F} \leq 0.025$ & 885442 & 70356 & 105969 & 154274 & 224359 & 223450 \\
\hline $0.025<\mathrm{F} \leq 0.05$ & 36536 & 3876 & 4698 & 5932 & 5947 & 5324 \\
\hline $0.05<\mathrm{F} \leq 0.10$ & 22454 & 1250 & 2212 & 4397 & 5381 & 4994 \\
\hline $0.10<\mathrm{F} \leq 0.15$ & 3371 & 98 & 179 & 236 & 659 & 728 \\
\hline $0.15<\mathrm{F} \leq 0.25$ & 11807 & 485 & 1137 & 1920 & 2632 & 2338 \\
\hline$F>0.25$ & 2744 & 215 & 345 & 495 & 627 & 772 \\
\hline Total & 962354 & 76280 & 114540 & 167254 & 239605 & 237606 \\
\hline $\begin{array}{l}\text { Total number of } \\
\text { individuals in the population }\end{array}$ & 6931329 & 744449 & 785488 & 889773 & 1136811 & 955605 \\
\hline
\end{tabular}

\footnotetext{
1: F=Inbreeding coefficient; ${ }^{2}$ : Includes animals born between 1990 and 2012
}

The sire was known for $81.81 \%$ of the animals included in our study. The most used 10 bulls had sired $10.61 \%$ of the population, and also, $9.06 \%$ of males themselves were the offspring of these bulls. Table 5 shows the number of individuals with known sires and the progeny per bull after 2002. 
Table 5- Number of individuals born between 2002 and 2012 with known sires recorded in the pedigree file

\begin{tabular}{lrrcrr}
\hline Birth Year & \multicolumn{2}{c}{$\begin{array}{c}\text { Number of Individuals } \\
\text { Total }\end{array}$} & $\begin{array}{c}\text { Proportion of } \\
\text { Sire Known }\end{array}$ & $\begin{array}{c}\text { Noviduals with } \\
\text { Known Sires, } \%\end{array}$ & $\begin{array}{r}\text { Average Progeny } \\
\text { per Sire }\end{array}$ \\
\hline 2002 & 112612 & 79079 & 70.2 & 2396 & 33.0 \\
2003 & 151632 & 94045 & 62.0 & 2982 & 31.5 \\
2004 & 225888 & 137198 & 60.7 & 2780 & 49.4 \\
2005 & 316635 & 201082 & 63.5 & 2154 & 93.4 \\
2006 & 540579 & 414312 & 76.6 & 2070 & 200.2 \\
2007 & 722436 & 609863 & 84.4 & 2376 & 256.7 \\
2008 & 744449 & 633740 & 85.1 & 2141 & 296.0 \\
2009 & 785488 & 667419 & 84.9 & 2221 & 300.5 \\
2010 & 889773 & 762775 & 85.7 & 2477 & 307.9 \\
2011 & 1136811 & 954243 & 83.9 & 2755 & 346.4 \\
2012 & 955605 & 821271 & 85.9 & 2365 & 347.3 \\
\hline
\end{tabular}

The proportion of individuals with known sires decreased until 2005. However, after that year, this proportion increased so much that nearly $85 \%$ of the individuals born after 2007 were the offspring of known sires. In addition, progeny per bull rapidly increased until 2012. As seen in Table 5, progeny per bull was 33 in 2002, but it went up to 347 in 2012.

Another finding of this study was that $13.88 \%$ of the registered Holstein Cattle population was inbred to some degree. After 2007, the proportion of inbred animals increased rapidly, but the inbreeding coefficient did not increase accordingly. It seems that the upward trend in the proportion of inbred animals is likely to continue, but this trend will not cause a significant increase in the inbreeding coefficient.

\section{Conclusions}

After calculating the inbreeding coefficients for the Holstein Friesian Cattle Population in Turkey, 13.88\% of these animals were determined to be inbred in the whole population between 1962 and 2012 . However, the average inbreeding coefficients of these inbred individuals was significantly low. This means that the percentage of inbred individuals in the population increased over time, while their mean inbreeding coefficient decreased. One reason for this development was that the gene flow from different countries in the population was quite high, and that the pedigree information had been considered while importing sperm, heifers and bulls. Another reason was the financial support of the government for artificial insemination and calves born from AI. Also, the AI technology has increased the use of same bulls' sperm for a long time in the population. Therefore, it has increased the number of distant relative animals. In other words, the chance of mating of distant relatives has increased. So, this has led to a large number of individuals with low inbreeding coefficients in the population. Besides, new farms were continually being added to the system, which meant that the cattle population in Turkey has gradually risen with the addition of these new animals. As a result of the study, it was determined that the level of inbreeding was not high except for some herds.

Owing to the continued import of live animals into the country, and the meticulous consideration of pedigree records in sperm imports, the inbreeding coefficient in Turkey is expected to follow the same trend without much increase.

\section{Acknowledgements}

We would like to express our thanks to the Cattle Breeders' Associations of Turkey (CBAT) for supplying the data utilized in this study.

\section{References}

Adamec V, Cassell B G, Smith E \& Pearson R E (2006). Effects of inbreeding in the dam on dystocia and stillbirths in US Holsteins. Journal of Dairy Science 89(1): 307-14. doi: 10.3168/jds.S0022-0302(06)72095-1

Bayram B, Güler O, Yanar M, Akbulut Ö, Aydın R, Bilgin Ö C \& Tüzemen N (2008). the level of inbreeding and its effects on some reproductive and milk yield traits in Holstein Friesian cattle reared in the agricultural faculty farm of Atatürk University. Journal of Animal Production 49(2): 1-6. (In Turkish)

Boldman K G, Kriese L A, Van Vleck L D, Van Tassel C P \& Kachman S D (1995). A manual for use of MTDFREML. A Set Programs to Obtain Estimates of Variances and Covariances. US Department of Agriculture, Agriculture Research Service. USA. ftp://aipl.arsusda.gov/pub/outgoing/mtdfreml/mtdfrman.pdf

Doekes H P, Veerkamp R F, Bijma P, Jong G, Hiemstra S J \& Windig J J (2019). Inbreeding depression due to recent and ancient inbreeding in Dutch Holstein-Friesian dairy cattle. Genetics Selection Evolution Volume 51, 54. doi: 10.1186/s12711-019-0497-z

Cleveland M A, Blackburn H D, Enns R M \& Garrick D J (2005). Changes in inbreeding of U. S. Herefords during the twentieth century. Journal of Animal Science 83: 992-1001. doi: 10.2527/2005.835992x. PMID: 15827243. 
Duru S (2012). Inbreeding and the importance of mating program on controlling inbreeding in Holstein cattle. Journal of the Faculty of Veterinary Medicine, Kafkas University, 18(4):701-704 DOI: 10.9775/kvfd.2012.6034 (In Turkish)

Falconer D S \& Mackay T F C (1997). Introduction to quantitative genetics (4 ${ }^{\text {th }}$ Edition). Longman Scientific and Technical, Harlow, UK. Chapter 3:57-63

Freyer G, Hernández-Sánchez J \& Cassell B G (2005). A note on inbreeding in dairy cattle breeding. Archives Animal Breeding, 48(2): 130137. doi: 10.5194/aab-48-130-2005

Gullstrand P (2015). Control of inbreeding in dairy cattle in the genomic era. Examensarbete / Swedish University of Agricultural Sciences, Department of Animal Breeding and Genetics, 485. On-line Publication: http://epsilon.slu.se

Hofmannova M, Pribyl J, Krupa E \& Pesek P (2019). Estimation of inbreeding effect on conception in Czech Holstein. Czech Journal of Animal Science 64(7): 309-316. doi:10.17221/154/2018-CJAS

Kaygisız A \& Kösetürkmen E (2007). Inbreeding level among Brown Swiss cattle and its effects on milk yield traits. KSU Journal of Science and Engineering 10(2), 124-131. (In Turkish)

Mc Parland S, Kearney J F, Rath M \& Berry D P (2007). Inbreeding trends and pedigree analysis of Irish Dairy and beef cattle populations. Journal of Animal Science 85: 322-331. doi:10.2527/jas.2006-367

Miglior F (2000). Impact of inbreeding- managing a declining Holstein gene pool. $10^{\text {th }}$ World Conference-Sydney-Australia.

Okumuş A, Kaygısız A \& Baş S (2010). Relationships with milk and reproduction traits of inbreeding in Holstein Cattle. KSU Journal of Natural Sciences 13(2): 30-38. (In Turkish)

Pryce J E, Haile-Mariam M, Goddard M E \& Hayes B J (2014). Identification of genomic regions associated with inbreeding depression in Holstein and Jersey Dairy cattle. Genetics Selection Evolution 46:71. doi: 10.1186/s12711-014-0071-7

Rokouei M, Torshizi V R, Shahabak, M M, Sargolzai M \& Sorensen A C (2010). Monitoring inbreeding trends and inbreeding depression for economically important traits of Holstein cattle in Iran. Journal of Dairy Science 93: 3294-3302. doi: 10.3168/jds.2009-2748

Sewalem A, Kistemaker G J, Miglior F \& Van Doormaal B J (2006). Analysis of inbreeding and its relationship with functional longevity in Canadian dairy cattle. Jornal of Dairy Science 89:2210-2216. doi: 10.3168/jds.S0022-0302(06)72291-3

Sorensen A C, Sorensen M K \& Berg P (2005). Inbreeding in Danish dairy cattle breeds. Journal of Dairy Science 88: $1865-1872$. doi: $10.3168 /$ jds.S0022-0302(05)72861-7

Thompson J R, Everett R W \& Hammerschmidt N L (2000). Effects of inbreeding on production and survival in Holsteins. Journal of Dairy Science 83:1856-1864. doi: 10.3168/jds.S0022-0302(00)75057-0

TUIK (2021). Retrieved on January 14, 2021, from http://rapory.tuik.gov.tr/15-01-2021-19:28:54-1874420587686368828239441645.html?

USCDCB (2021). Animal Improvement Programs Laboratory. Retrieved on January 12, 2021, from https://queries.uscdcb.com/eval/summary/inbrd.cfm

Weigel K A (2001). Controlling inbreeding in modern breeding programs. 2001. Journal of Dairy Science, 84(E. Suppl.):E177-E184. doi: 10.3168/jds.S0022-0302(01)70213-5

Weigel K A \& Lin S W (2002). Controlling inbreeding by constraining the average relationship between parents of young bulls entering AI progeny test programs. Journal of Dairy Science 85: 2376-2383. doi: 10.3168/jds.s0022-0302(02)74318-x

Wiggans G R \& VanRaden P M (1995). Calculation and use of inbreeding coefficient for genetic evaluation of United States dairy cattle. Journal of Dairy Science 78: 1584-1590. doi: 10.3168/jds.S0022-0302(95)76782-0

Wright S (1922). Coefficients of inbreeding and relationships. The American Naturalist 56: 330-338

(C) 2022 by the author(s). Published by Ankara University, Faculty of Agriculture, Ankara, Turkey. This is an Open Access article distributed under the terms and conditions of the Creative Commons Attribution (CC BY) license (http://creativecommons.org/licenses/by/4.0/), which permits unrestricted use, distribution, and reproduction in any medium, provided the original work is properly cited. 